Univerzitet u Beogradu
Poljoprivredni fakultet
Institut za poljoprivrednu tehniku
Naučni časopis
POLJOPRIVREDNA TEHNIKA
Godina XLV
Broj 2, 2020.
Strane: $79-87$

\title{
MEASUREMENT BRIDGE FOR LARGE GRAIN MOISTURE CONTENT DETERMINATION
}

\author{
Muhanned AL-Rawi ${ }^{* 1}$ \\ ${ }^{1}$ Ibb University, Yemen
}

\begin{abstract}
This paper describes the development of a moisture-measuring instrument suitable for large grains. The paper seeks to do the measurement based on the propagation of microwaves through materials of different moisture levels. The principle of operation here is sending an equally divided signal through both arms of the bridge and comparing the output signals' properties to determine the moisture content of the grains. The design of the bridge using waveguide and coax technology is presented.
\end{abstract}

Key words: Measurement bridge, grain moisture content determination, waveguide.

\section{INTRODUCTION}

A waveguide is a structure that guides waves, such as electromagnetic or sound waves. There are different types of waveguides for each type of wave. The original and most common is a hollow conductive metal pipe used to carry high frequency radio waves, particularly microwaves.

The geometry of a waveguide reflects its function. Slab waveguides confine energy to travel only in one dimension, fiber or channel waveguides for two dimensions. The frequency of the transmitted wave also dictates the shape of a waveguide; an optical fiber guiding high-frequency light will not guide microwaves of a much lower frequency. The width of a waveguide needs to be of the same order of magnitude as the wavelength of the guided wave.

\footnotetext{
*Corresponding Author. E-mail: E-mail: muhrawi@yahoo.com
} 
Waves propagate in all directions in open space as spherical waves. The power of the wave falls with the distance $R$ from the source as the square of the distance. A waveguide confines the wave to propagate in one dimension, so that, under ideal conditions, the wave loses no power while propagating. The conductors generally used in waveguides have small skin depth and hence large surface conductance. Due to total reflection at the walls, waves are confined to the interior of a waveguide. The propagation inside the waveguide, hence, can be described approximately as a "zigzag" between the walls. This description is exact for electromagnetic waves in a hollow metal tube with a rectangular or circular cross-section.

Microwaves have made their applications in various areas; and have been used in moisture content determination. This has been an improvement from the traditional methods where the sample, in this case grains had to be dried in order to determine the moisture content. This meant the methods used earlier were destructive and it was not possible to recover the sample. Microwaves are a non-destructive method for determining the moisture level of grains. The sample is recovered as was before being used.

Product quality assurance especially in the agricultural sector is a challenge especially in processing industries. Moisture content in grains can also lead to great losses due to the weight of the water content and also fungal infections in grains which could lead to great losses for farmers.

The paper objective is to accurately determine the moisture content in grains by determining the attenuation and phase and their relationship with dielectric constant/relative permittivity of microwaves when transmitted through the sample. Some researches that discuss the topic of this paper can be found in literatures[1-5].

\section{2- System design}

The design specifications define the working of a bridge at microwave frequencies. The bridge is designed using microstrip and coax technology. The input signal is taken through a power splitter which splits the power into equal halves. Each side of the bridge has a cavity fed by the microstrip transmission line. The lower arm is used as the datum and samples placed in the cavity of other arm. The output signals from either arm are then mixed and filtered to obtain the output signal.

\subsection{Design of power splitter}

Wilkinson splitter shown in Fig.1 works as a power divider, when a signal enters port 1 , it splits into equal-amplitude, equal-phase output signals at ports 2 and 3 . Since each end of the isolation resistor between ports 2 and 3 is at the same potential, no current flows through it and therefore the resistor is decoupled from the input.

The two output port terminations will add in parallel at the input, so they must be transformed to $2 \mathrm{xZ}_{0}$ each at the input port to combine to $\mathrm{Z}_{0}$. The quarter-wave transformers in each leg accomplish this; without the quarter-wave transformers, the combined impedance of the two outputs at port 1 would be $\mathrm{Z}_{0} / 2$. The characteristic impedance of the quarter-wave lines must be equal to $1.414 \times \mathrm{XZ}_{0}$ so that the input is matched when ports 2 and 3 are terminated in $\mathrm{Z}_{0}$. 
The signal from the input is equally divided between the two arms of the Wilkinson power divider before being fed to the microstrip transmission line. The practical circuit of Wilkinson splitter is shown in Fig.2.
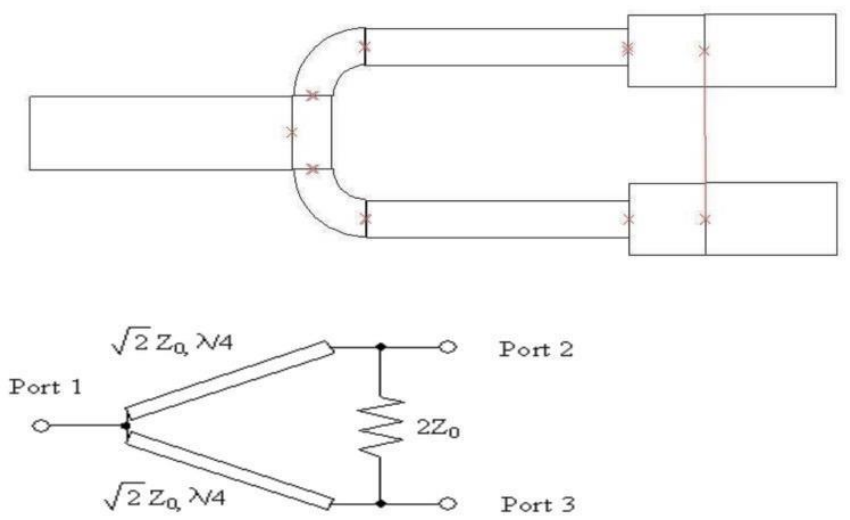

Figure 1. Wilkinson splitter

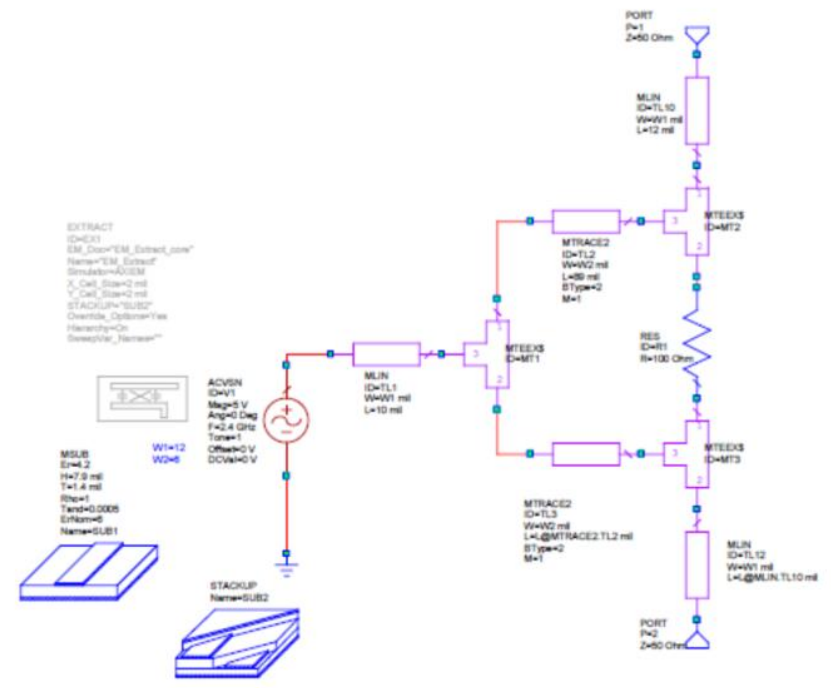

Figure 2. Practical Circuit of Wilkinson splitter

\subsection{Design of microstrip transmission line}

The microstrip design includs determination of the various parameters for optimal working condition of the line. Microwave office offers a design window for specifying the various parameters of the microstrip. The parameters to be specified include the following: 
- Operating frequency

- Electrical length

- Impedance

- Dielectric constant

- Dielectric

The length, width, height and thickness of the microstrip can then be obtained from the parameters specified above.

The sub-circuit in Fig. 3 shows the power splitter and the microstrip line. The parameters for the line are specified and the substrate values given also for each m-sub.

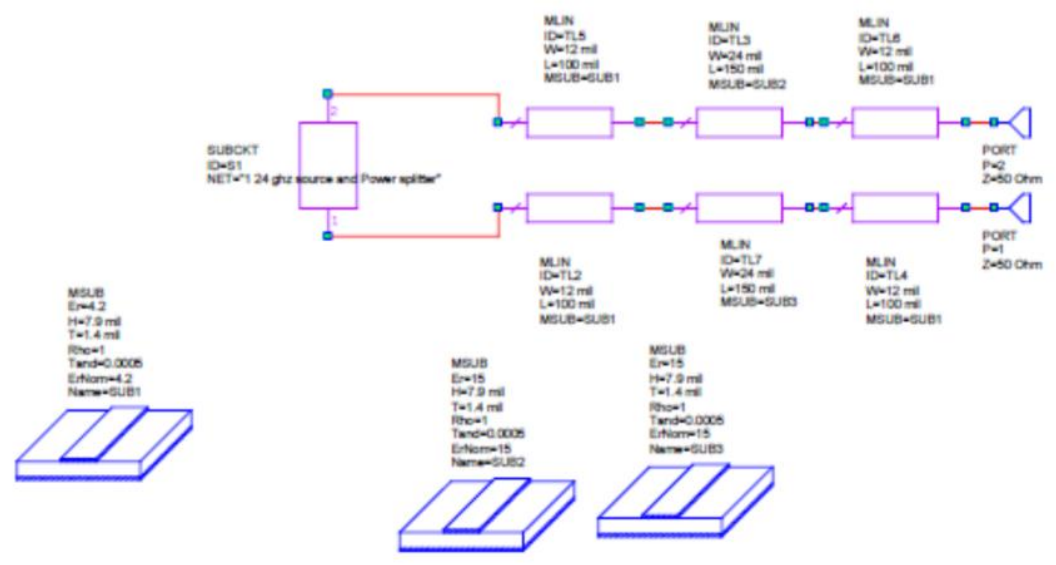

Figure 3. Power splitter and micro strip line

\subsection{Design of the cavity}

The design of the cavity involves determination of the sample holder parameters for optimal working conditions. The cavity parameters are determined using mathematical computations. Two cavities, one in each arm are used in the circuit. One cavity is maintained as the datum and the other cavity is where the grains whose moisture is to be determined are placed. The signal outputs from the cavity are then transmitted by the microstrip line to the mixer.

\subsection{Design of mixer}

The mixer in the circuit works to multiply the signals from either arm of the bridge and produce a single output whose properties are dependent on the two input signals.

The ideal mixer, is a device which multiplies two input signals. If the inputs are sinusoids, the ideal mixer output is the sum and difference frequencies, typically, either the sum, or the difference frequency is removed with a filter. 
Important properties of the mixer that are put into consideration in the design of the mixer include:

- Conversion gain or loss - lowers the noise impact of following stages.

- Intercept point (linearity) - impacts receiver blocking and interferer performance.

- $\quad$ Ports isolation (LO-to-RF, LO-to-IF, RF-to-IF) - want to minimize interaction between the RF, IF, and LO ports.

- Noise figure - impacts receiver sensitivity.

- High-order spurious response rejection.

- Image noise suppression - improves system noise figure.

- Operating frequency range.

The circuit showing the mixer specifications and the two signals being fed to it is as shown in Fig.4.

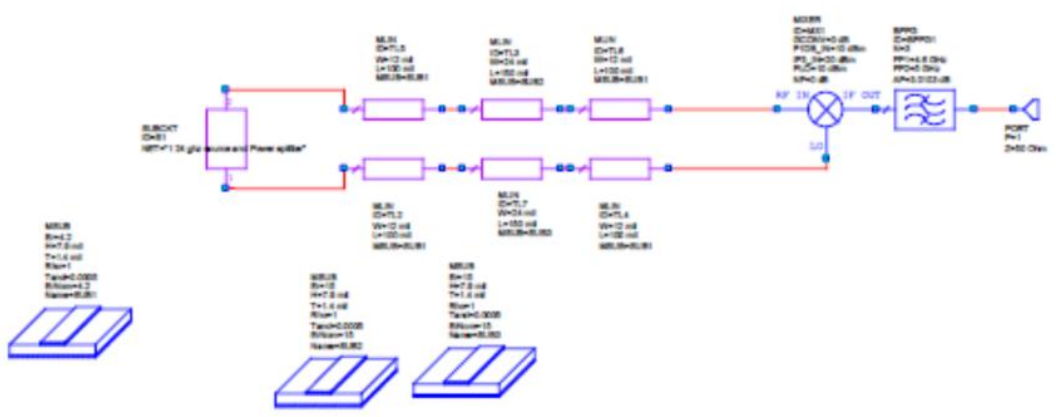

Figure 4. Mixer circuit

\section{Simulation results \\ 3.1 Power splitter analysis}

Simulation results for the power splitter showing the power being split into two equal halves as shown in Fig.5.

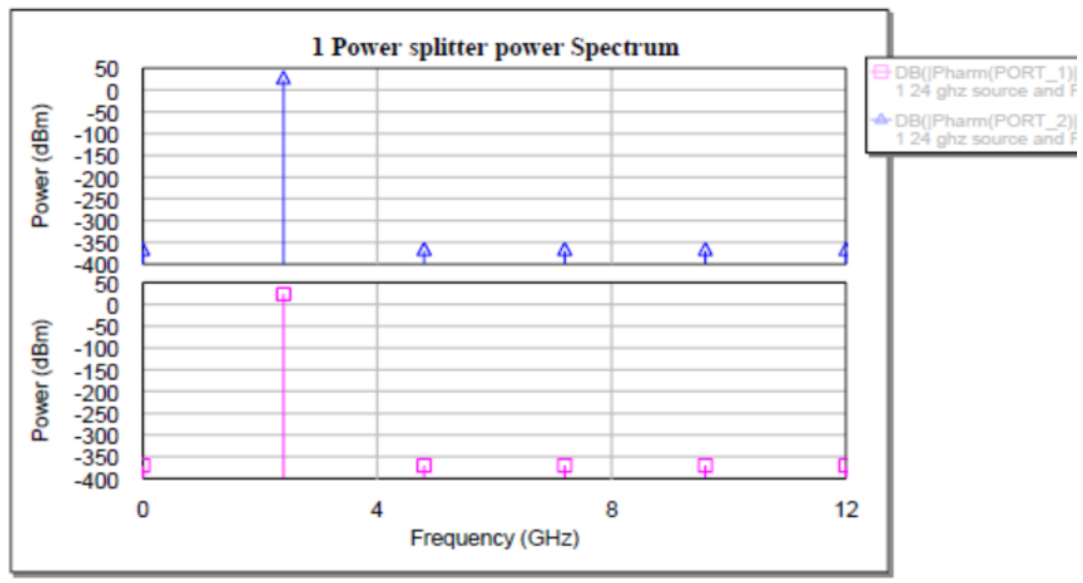

Figure 5. Power splitter result 


\subsection{Output from power splitter and transmission line}

With both cavities empty (having the same value of dielectric) simulated results shown in Fig.6 indicate equal distribution of power in each arm of the bridge.

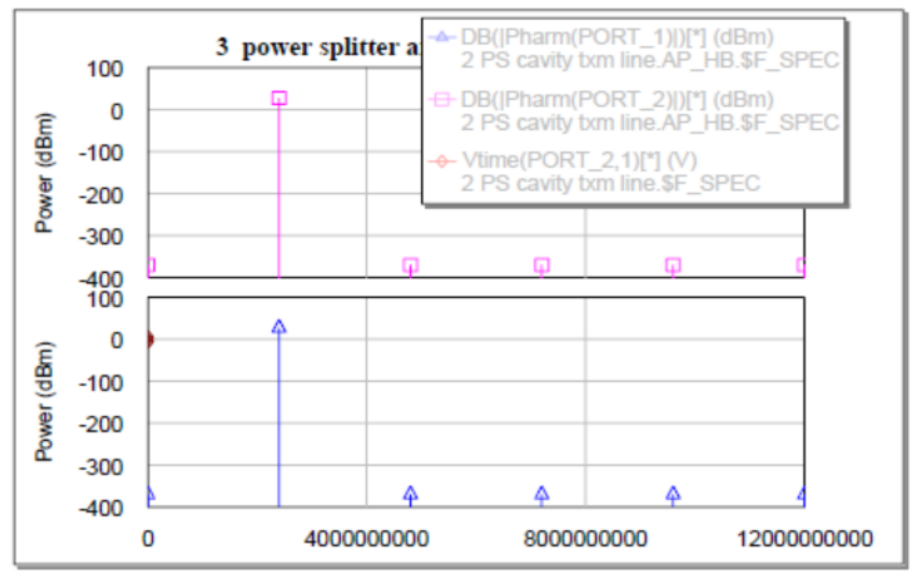

Figure 6. Output from power splitter and transmission line

\subsection{Output voltage from mixer}

The output voltage from the mixer is shown in Fig.7.

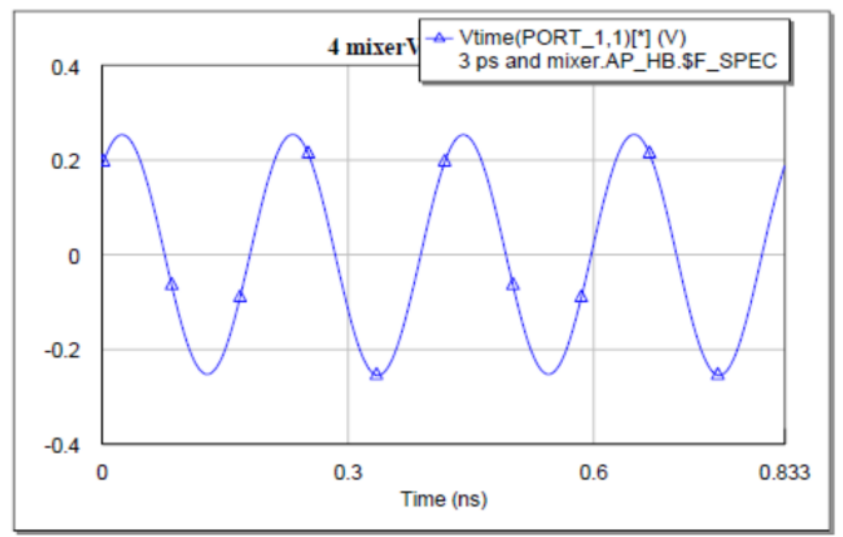

Figure 7. Output voltage 


\subsection{Output graph}

\subsubsection{Relationship between phase shift and dielectric constant}

Variation of dielectric constant results in shifting of the phase of the two signals as shown in Fig.8.
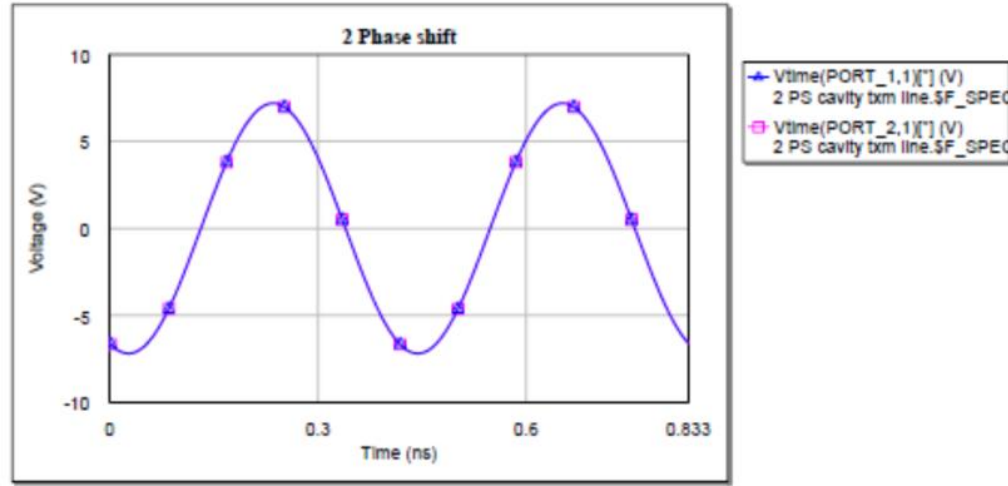

Figure 8. Results showing the phase shift of the two signals

\subsubsection{Graph of phase against dielectric constant}

The relationship between phase and dielectric constant is shown in Fig.9.

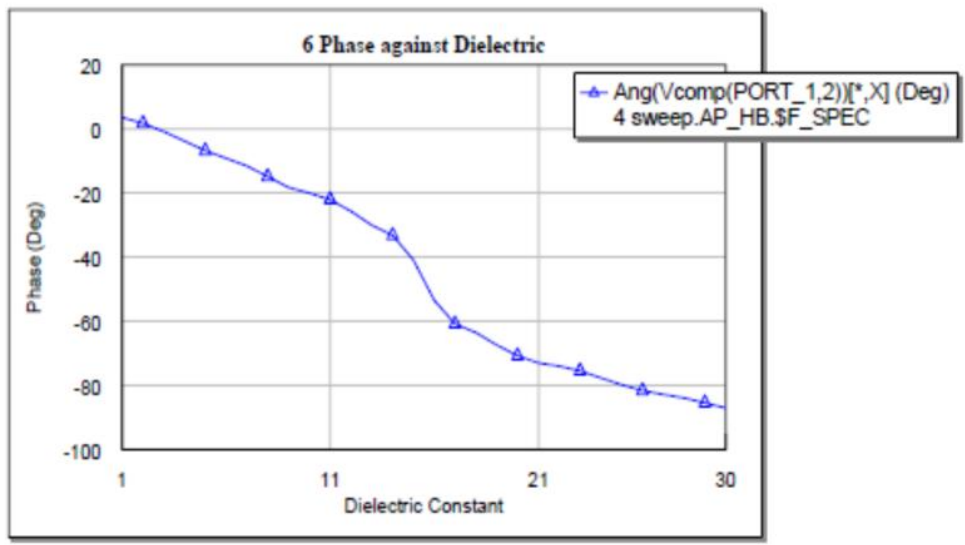

Figure 9. Relation between phase and dielectric constant 


\subsubsection{Graph of dielectric constant against power}

The relationship between dielectric constant and power is shown in Fig.10.

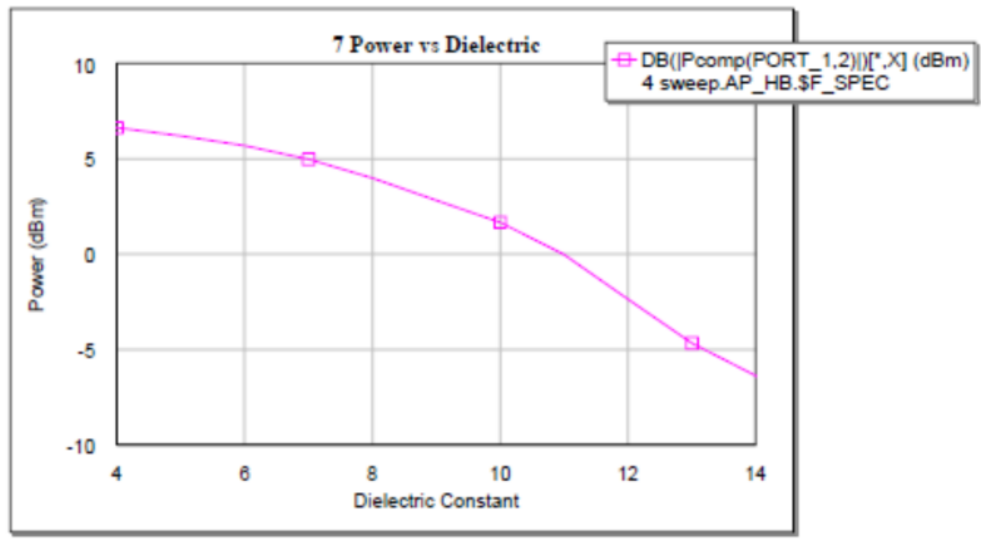

Figure 10. Relation between power and dielectric constant

\section{CONCLUSIONS}

The objectives of the paper were met though with several challenges. It was successfully observed that microwaves and waveguide technology would be an effective method to determine the moisture content in grains without destruction of the grain samples.

\section{BIBLIOGRAPHY}

[1] W. Wang.2015. Design and development of a resistive grain moisture meter. Applied Mechanics and Materials. Vol. 716-717, pp. 961-964.

[2] Z. Liu, Z. Wu .2015. Research on online moisture detector in grain drying process based on V/F conversion. Mathematical Problems in Engineering.Vol.2015, pp.1-10.

[3] M. Zhiwei, L. Changyou and W. Biying. 2016. Design and test of grain moisture online measuring system based on floating ground capacitance. 5th International Conference on Measurement, Instrumentation and Automation. China.

[4] S. Sius, and K. Christopher. 2017. Development of resistance type moisture measuring device for grains. Leonardo Electronic Journal of Practices and Technologies.Issue 30, pp. 255-268.

[5] A. Rai, B. Dass, and V. Tiwari. 2018. Design of a probe type in situ electronic grain moisture measurement system. Bioscience Biotechnology Research Communications. Vol.11, No.2, pp. $246-250$ 


\title{
MERNI MOST ZA ODREĐIVANJE SADRŽAJA VLAGE ZA VELIKE KOLIČINE ZRNA
}

\author{
Muhanned AL-Rawi ${ }^{1}$ \\ ${ }^{1}$ Ibb University, Yemen
}

Sažetak. Ovaj rad opisuje razvoj pogodnog instrumenta za merenje sadržaja vlage u velikim količinama zrna (npr. skladišta, silosi). U radu se prikazuje merenje na osnovu prostiranja mikrotalasa kroz zrnaste ili slične materijale u masi različitih sadržaja vlage. Princip rada instrumenta je slanje podjednakih signala kroz oba kraka mernog mosta i upoređivanje osobina izlaznih signala radi određivanja sadržaja vlage u masi zrna. Predstavljen je dizajn mernog mosta sa korišćenjem prostiranja talasa kroz cevi i tehnologija koaksijalnih (optičkih) kablova .

Ključne reči: Merni most, određivanje sadržaja vlage u zrnu, talas

$\begin{array}{ll}\text { Prijavljen: } & \\ \text { Submitted: } & \\ \text { Ispravljen: } & \\ \text { Revised: } & 02.02 .2020 .2019 . \\ \text { Prihvaćen: } & \\ \text { Accepted: } & 25.05 .2020 .\end{array}$

